\title{
Interlanguage Error of ESL Students in English Writing Assignment
}

\author{
Kadek Heni Oktarina Wisudayantia ${ }^{\mathrm{a}}$, Putu Desi Anggerina Hikmaharyanti ${ }^{\mathrm{b}}$ \\ kadekoktarina09@gmail.com \\ ${ }^{a}$ STKIP Agama Hindu Singaraja, 81113, Indonesia

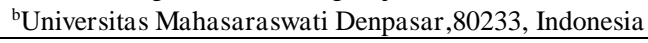

\begin{abstract}
This study aimed at (1) analyzing the types of interlanguage errors in English writing assignment committed by $2^{\text {nd }}$ semester students at STKIP Agama Hindu Singaraja, Bali, (2) analyzing dominant type of interlanguage errors in English writing assignment committed by $2^{\text {nd }}$ semester students at STKIP Agama Hindu Singaraja, Bali, (3) describing the causes of interlanguage errors. The method applied is descriptive qualitative in nature with the subjects were 33 students of $2^{\text {nd }}$ semester in academic year 2020/2021 at STKIP Agama Hindu Singaraja, Bali. The methods were used in this study were identifying the errors, classifying the errors, describing the frequency of errors, describing the dominant type of errors, and describing the causes of errors. There were 70 errors which are divided into three main categories, namely: morphological level (62), syntactical level (5), and discourse level (3) according to James (1998). The dominant type of error in this study was the word spellings in morphological level with the total number of errors were 46 errors. The causes of interlanguage error in students' writing namely interlingual transfer. Interlingual transfer is influenced by the structure of mother tongue.
\end{abstract}

Keywords: Interlanguage error; ESL student; English writing

\section{Introduction}

English has become an international language and the most spoken languages in the world. All language learners have possibility to make mistakes regardless the language they are learning, which is normal for those who study a second or foreign language. Identifying and analyzing students' errors become crucial as it enables teacher to diagnose the difficulty the students may encounter in the classroom. While for students, showing their error can be a significant input as a learning tool to improve their studying. Learners' errors is particularly importance as the making of errors can be a device that the learners use in order to learn (Nurwahida, 2021). Error analysis has become an interesting topic in the study of a second language acquisition. It has been proven by the number of studies focusing on the students' errors in writing. Many EFL learners think in their first language and they used direct translation when they speak and write in L2. Since they have more than one language in hand, it brings more problems. ESL learners tend to switch those languages interactively, causing some confusion in the structure and meaning. Analysis and classification of the cause of confusion enable learners to have a clearer view of their problems and thus, able to produce better written texts. Traditionally, ESL instruction has focused on teaching the grammar or the language, with a plenty of concentration on the verb tense system. Recently, more attention has been given to vocabulary, often divided into categories like "colour" or "animals" (Wisudayanti, 2021). Selinker (1997), interlanguage is a language system that has developed in the minds of language learners that learn a second language. Ellis (1997) state that the interlanguage is the learner language. Interlanguage system is mix between native language and target language. The fact that learners do make error and these error can be observed, analyzed 
and classified to reveal some things of the system operating within the learner led to a surge of study learners error. Error analysis is conducted to identify strategies which learners use in language learning, try to identify the causes of learner errors, and to obtain information on common difficulties in language learning, as an aid to teaching or the preparation of teaching materials (Richards, 1992). One of the aims of error analysis is to help teachers give assessment more correctly what remedial work would be needed for the learners of English (Wisudayantia, 2018). Writing is one of skills in English that should be taught integrated. It is productive and expressive activity. Writing is one of important skills in which students can improve the language in it. According to Wiley \& Sons (2000) "writing is a key to successful school experiences and essential means of communication that helps students learn how to structure and organize their thoughts". It means the students make writing as a communication tool for learning. Moreover, Clark (2007) explains writing is a instrument of thinking that allows students to express their thoughts. It means that the students can write what they think.

According to Nunan (2003) "Writing is both a physical and a mental act. On the other hand writing is the mental work of inventing ideas, thinking about how to express them, and organizing them into statement and paragraph that will be clear to reader". Another definition in Harmer (2007), "Writing is the stage of writers goes through in order to produce something in its final written form". It means that writing is both a process and a product. Writer imagines, organizes, edits, reads and rereads. They express an idea or feeling about something and then they start to write. The purpose of writing is for communication, and it can be used as the medium of the writer to communicate with the reader. The writer can express and explain their ideas to other by writing something, they usually use many tool to assist in their writing such as dictionary. Dealing with writing, the writer makes the best use of sentence to express the message. The purpose is communication when the writer writes. The writer intends to interact with their readers using written language.

The study of language in the twentieth century intended to concentrate on spoken language. Written language was though by some to be spoken language put into written form. This, however, contributed to the fact that writing was for long a time a neglected area in language teaching. Writing, indeed, is different from speaking. In writing, one needs some conscious mental effort. One needs to think out his or her sentences and to conceder to yield a good composition. To achieve such as composition, a writer must have adequate skill of writing. Writing skills can be seen from the writer's content, organization, vocabulary or word choice, grammatical, mechanic (Ganesse and Upshur, 1996)

So, the good composition of a texts are include content, organization, vocabulary or word choice, grammatical, mechanic.

\section{a. Content}

In writing one has to keep the channel of communication open through his or her own effort and to ensure, both through his or her choice of sentences are linked together and sequenced, the text he or she produce can be interpreted on its own. One has to master the written of the language and to learn certain structures, which are used in speech, or perhaps not used at all, but which are important for effective communication in writing. This not only has a psychological effect, it may also cause a problem in term of content what to say.

b. Organization

Organization is the the structural framework for that writing. Organization is important to effective writing because it provides readers with a framework to help them fulfill their expectations for the text. A wellorganized piece of writing supports readers by making it easy for them to follow, while a poorly organized piece leads readers through a maze of confusion and confounded or unmet expectations. (http://www.learnnc.org/lp/editions/few/683)

c. Word choice

Another aspect with can show the writer's skill is the word choice. The writer must use words that his reader can understand easily. The uses of words which have obscure meaning, jargons, or abberaviation have 
to be avoided or used with great consideration. Raimes (1983) claims that " there are 3 term of word choice, that is vocabulary, idioms, and tone"

\section{a. Grammar}

As a matter of fact, writing using strict, standard grammar encourages one to become careful, disciplined and responsible writers. These three qualities will lead one to make further progress. Grammar controls what one writers, it judges wheter one follows or breaks the language rules, consequently, writers who keep on breaking the basic grammar rules might be regarded as careless (Bram,1995).

b. Mechanics

Mechanics includes spelling and punctuation also play important role in writing. This section asseses the value of these feature as part of the resources of the written form of the language and therefore their relative importance in writing programmed.

1) Spelling

Spelling is the important thing than having opportunities to apply their emerging knowledge of the alphabetic principle to their own writing. (http://www.learnnc.org/lp/editions/few/679)

2) Punctuation

Punctuation is the system of separating written words by the use of punctuation mark the periods, comma, semicolon. Punctuation is fundamentally a means of making boundaries and relationship between the grammatically units of written text

In teaching English especially writing skill, the teacher has to understand what is teaching writing itself. Considering all components that involve in delivering the materials in teaching writing, many strategies can be done by the writing teacher. Hyland (2013) clarifies that teaching writing predominantly involves developing learners' skill in producing fixed patterns, and responding to writing means identifying and correcting problems in the students' control of the language system. It means that, writing is a complex process where it is not only about constructing some sentences into paragraph. According to Urquhart and Mclever (2006), teaching writing is a unique in this way. It benefits both teacher and students, serving as communication vehicle, assessment tool, and intelectual exercise. Teaching writing is very useful for teachers and students

This research was descriptive qualitative research in nature. Descriptive qualitative research was designed to describe the interlanguage errors in English writing assignment committed by $2^{\text {nd }}$ semester students at STKIP Agama Hindu Singaraja, Bali, to identify the types of error in recount text based on linguistic category and surface taxonomy strategy, explains either the dominant types of errors or the dominant sources of errors as well as describe the causes of interlanguage error. The characteristic of this descriptive qualitative research is there was no control of treatment as in an experimental one. The subjects of this study were 33 students of $2^{\text {nd }}$ semester in academic year 2020/2021 at STKIP Agama Hindu Singaraja, Bali. The data were erroneous sentences found in English writing assignment committed by $2^{\text {nd }}$ semester students at STKIP Agama Hindu Singaraja, Bali. In this study, the researcher used elicitation method in her research to obtain the data accurately. The steps were used in collecting the data were as follows: the writer collected the data containing erroneous sentences from English writing assignment committed by $2^{\text {nd }}$ semester students at STKIP Agama Hindu Singaraja, Bali, the writer identified the writing production, as well as read and marked the types of errors found in English writing assignment produced by $2^{\text {nd }}$ semester students at STKIP Agama Hindu Singaraja, Bali. After that, the writer wrote the erroneous sentences and classified all types based on linguistic category and surface strategy taxonomy. According to James (1998), the surface strategy taxonomy is a classification system based on the ways in which the learner's erroneous version is different from the presumed target version. This surface strategy taxonomy can be the ways to highlight the errors made by the learners or the deviation of L1 learners in making errors. For example, learners may omit necessary items or add unnecessary items; they sometimes may misform or misorder them. The researcher analyzed the data by using descriptive qualitative analysis as following steps: identifying the errors, classifying the errors, the 
frequency of errors, describing the dominant type of errors, describing the causes of errors, and the researcher concluded this study.

The researcher discussed the finding of interlanguage errors in recount text and discussion from the English writing assignment committed by $2^{\text {nd }}$ semester students at STKIP Agama Hindu Singaraja, Bali.

1. Types of Error in Morphological Level

Morphology concerns about how the words shaped by combining morphemes that can be attached with the base forms. Here, the learners made errors in the case of bound morpheme, word form, the use of word class, code switching, and literal translation. In the type of morphological errors, the researcher found 62 errors. The errors were classified into 3. They were bound morpheme 1, word spelling 46, and 15 literal translation.

The first type of error is bound morpheme. In the case of bound morpheme, the student omitted the suffix-s in making the plural nouns. The student wrote My friend instead of my friends. For example: Last month I and my friend went to Pandawa Beach supported by Krisna Oleh-oleh. Here, the error occured because the learner omitted the suffix-s. The word "my friend" should be added by-s because it indicated all the students who joined in the tour.

The second error is word. Error in the case of word is divided into 4 namely, word spelling, noun, verb, and adjective. However, in this research, the researcher only found the error in the form of word spelling. There were 46 errors in the word spelling. Word spelling occured because the learner forgot the graphological system and its spelling. For example: "Last moont, my school had tour to Pandawa Beach. Here, the student used wrong spelling. The wrong spelling appeared on the word "moont", it made the word meaningless. Thus, the correct word is "month". In the case of noun, the student used the incorrect words form. For example: "I saw Balinese souvenirs like blacelet, neekalce, and T-shirt". Here, the student should use the correct noun like bracelet and necklace. In term of adjective, the student used the incorrect adjective, for example "I'm very happy because Pandawa beach has beautifull view". Here, the student should write "beautiful" rather than "beautifull". In the case of verb, student also used the incorrect verb, for example in the case of the use of the verb. "We visted Bajera Sandi and Pandawa Beach". The student should write visited instead of visted.

The third error is literal translation. Literal translation occurred when the learner translated the word one by one according to the dictionary. He didn't consider about the context of the text. The researcher found 15 errors. For example: "After that, we went to By - by Krisna". Here, the student translated words "Oleh-oleh Krisna" one by one. So that, the words became "by-by Krisna". In this case, the student didn't need to translate the name of the place. It is because the name of the place already given by the owner of the place itself. Thus, the student should write the original name of the place such as: "Oleh-oleh Krisna". Another example is "I playing in the beach". Here, the student also translated the words one by one. In his concept, the sentence "Saya sedang bermain di pantai" translated into English form, then the word "saya" became "I", and "bermain" became "playing". Unfortunately, the learner didn't put to be in this sentence, on the other hand, to be is needed to construct simple past continuous tense. So that, the student should write "I was playing in the beach".

\section{Types of Error in Syntactical Level}

Syntax is how the words are put and linked together with others. Syntax is very useful to combine the words together with the rules system of L2. In recount text, the learner made errors in term of syntax with the total number of errors 5 errors. Syntactical error is clasified into 8, they were phrase, clause, sentence, tenses, $\mathrm{BE}$, article, pronoun, and conjunction. However, in this study the researcher only found syntactical error in the form of phrase. The researcher found 5 errors. The researcher divided this part into 4 namely: adverb phrase, adjective phrase, noun phrase, and gerund phrase. In this study, the researcher only found error in the form of adverb phrase and adjective phrase. The first error is, adverb phrase. Adverb phrase is a phrase that consists of 2 or 3 words that its head is adverb. The error occurred in term of redundancy or the repetition of unnecessary 
elements. For example: We visited Krisna Resto in this afternoon. In this sentence, the learner made repetition by using preposition "in". Actually, there was no adverb phrase needed in the words "this afternoon". Here, the learner had concept if it is translated into bahasa the sentence would be "Kami mengunjungi Krisna Resto pada siang hari". However, because there was a determiner "this" which is reffering to "ini" in this sentence, so that adverb phrase is not require in the sentence. Besides that, in the case of adjective phrase the researcher found 1 error in the category of misordering. For example: "The view in Pandawa beach beautifully". The learner used the wrong order in predicative adjective phrase. When the word is predicative, it should be followed by linking verb that modifies and it should appear in the soutside of noun phrase for instance, "is" function as predicate. Then the head of its adjective phrase should be placed in the end. Thus, the right sentence would be "The view in Pandawa beach is beautiful".

\section{Types of Error in Discourse Level}

Discourse is used to communicate something that must be coherent. A good discourse doesn't create the ambiguity between sentences or paragraphs, therefore it doesn't emerge new prespective about them. The errors occurred when the learner didn't aware with the elements of discourse which have relationship to connect the meanings of one sentence to the others, therefore the discourse will be coherent. The elements of discourse, namely: substitution, reference, ellipsis, conjunction, and lexical conjunction. In this study, the researcher only found 1 type of error in discourse namely conjunction with the total number of errors were 3 errors. For example: “In Krisna Oleh-oleh I bought bracelet, necklace”. Here, the student didn't put any conjuction to connect one word to another word. The learner should put "and" to the sentence, so that, the sentence would become "In Krisna Oleh-oleh I bought bracelet and necklace". Another example of error omitted by the student is in term of conjuction such as: "I was buying T-shirt and souvenir and My family and I back to home". In this sentence, the learner put so many conjuction "and" in his sentence. The learner should write the correct sentence for instance, "I bought T-shirt and souvenir, after that My family and I back to home".

\section{Dominant Type of Error}

Based on the analysis in this study, there were only 3 types of interlanguage error are found in the recount text committed by students $2^{\text {nd }}$ semester at STKIP Agama Hindu Singaraja, Bali, as follows: 62 errors in the morphological errors, 5 errors in the syntactical level, and 3 errors in the discourse level. Thus, the dominant type of error in this study was the word spellings in morphological level with the total number of errors were 46 errors.

\section{The Causes of Error}

From the analysis that had been conducted by the researcher in students' writing in at SMP Negeri 1 Seririt, there were several causes of students' error in second language acquisition, namely: Interlingual transfer and Intralingual transfer. In this study, the researcher found 70 errors. First, interlingual transfer is influenced by the structure of mother tongue. The errors were classified into 3, namely: transfer of morphological elements, transfer of Indonesian grammatical structure into English, and transfer of words. In the case of transfer of morphological elements, the researcher found 62 errors. For example: "Last month I and my friend went to Pandawa Beach supported by Krisna Oleh-oleh. Here, the error occurred because the learner omitted the suffix-s. The word "my friend" should be added by-s because it indicated all the students who joined in the tour.

In the term of Indonesian grammatical structure into English in which the words are translated from L1 to L2. The error occurred in the student's sentence, for instance: I playing in the beach". Here, the student also translated the words one by one. In Indonesian, there was no TOBE to link the predicate in the nominal sentence. However, when the learner had concept in his mind that "Saya sedang bermain di pantai" can be translated into English form, then the word "saya" became "I", and "bermain" became "playing". Unfortunately, the learner didn't put to be in this sentence, on the other hand, to be is needed to construct 
simple past continuous tense. So that, the student should write "I was playing in the beach". Second, Intralingual error is influenced by the partial learning of L2 system or the structure of the target language. The students' error in term of intralanguage, for instance is overgeneralization. The example of overgeneralization is "Before we back to our school, the teacher give the informations to the students". This kind of error indicates the overgeneralization because the student used the form of suffix-s to extend the word "information". Information belongs to uncountable-noun; therefore, it cannot be added by suffix-s. However, in this study, the researcher only focused on interlanguage errors. Thus, the researcher didn't discuss the intralingual causes in this study.

\section{CONCLUSION}

A study of an analysis of interlanguage errors found in English writing assignment committed by $2^{\text {nd }}$ semester students at STKIP Agama Hindu Singaraja, Bali was conducted in order to identify the phenomenon of interlanguage error. Regarding to the statement of the problems, there were six main conclusion in this study. First, the students' English writing assignment contain a lot of erroneous sentences. The researcher used Surface Strategy Taxonomy and Linguistic Category in analyzing the data. In this research, the research found 70 errors which are divided into three main categories, namely: morphological level, syntactical level, and discourse level. Second, morphological level consists of 62 errors including: bound morpheme 1, word spelling 46, and literal translation 15. Third, in the syntactical errors there were only two types of syntactical error found in students' English writing assignment which consist of 5 errors including: phrase 4, and adjective phrase 1. Fourth, in the discourse level there were 3 errors found in the English writing assignment namely conjunction. Fifth, the most dominant type of error in this study was the word spellings in morphological level with the total number of errors were 46 errors. In his study, the researcher found the causes of students interlanguage error in students' writing namely interlingual transfer. Interlingual transfer is influenced by the structure of mother tongue. The last, the researcher realizes that this research is still far from perfect. The researcher hopes that for the next researcher who wants to do the same research is expected to improve this study by conducting a deeper analysis of the causes of interlanguage error. Besides that, the contributions are needed in order to reduce the occurrence of interlanguage error in writing. Thus, the students can write English in a good form.

\section{References}

Brown, H.Douglas. (1994). Teaching by Principles. New York: Prentice Hall.

Bram, Barli.(1995). Write Well Improving Skills. Yogyakarta: Kanisius

Clark,Sarah Kartchner. (2007). Writing Strategies for Science. USA : Shell Education.

Ellis. (1986). Understanding Second Language Acquisition. New York. Oxford University Press.

(1997). The Study of Second Language Acquisition. Oxford: Oxford University Press

Geneese, Fred and Upshur, John A. (1996). Classroom Based Evaluation in Second Language Education. Cambridge: Cambridge University Press.

Harmer, Jeremy. (1991). The practice of English language teaching. USA: Longman Group.

Hyland,Ken. (2013). Second Language Writing. Hongkong: Cambridge University Press.

James, Carl. (1998). Errors in Language Learning and Use: exploring Error Analysis. London: Longman. 
Malone, Susan. (2012). Theories and Research of Second Language Acquisition. Bangkok. Retrieved on: http://www.sil.org/sites/default/files/files/theories_and_research_of_second_language_acquisition.pdf

Kadek Heni Oktarina Wisudayanti, \& Putu Desi Anggerina Hikmaharyanti. (2021). THE CAPACITY OF PRAGMATICS IN ESL TEACHING OF ENGLISH STUDENTS IN BULELENG REGENCY. SPHOTA: Jurnal Linguistik Dan Sastra, 13(1), 12-21. https://doi.org/10.36733/sphota.v13i1.1522

Kuarniawati, Ari. (2014). Interlanguage Errors found in Islamic English Speech Texts "Contoh-Contoh Pidato 3 Bahasa". Muhammadiyah University of Surakarta. Retrieved on: http://eprints.ums.ac.id/28642/1/COVER.pdf.

Nunan, David. (2003). Practical English Language Teaching. New York: The Mc Graw Hill Companies.

Nurwahida. (2021). Error Analysis in ESL Writing: A Case Study at Academic English Program at St. Michael's College, VT. International Journal in Applied Linguistics of Parahikma,1 (1), 77-84

Wisudayanti, K. H. (2021). THE CAPACITY OF PRAGMATICS IN ESL TEACHING OF ENGLISH STUDENTS IN BULELENG REGENCY. SPHOTA: Jurnal Linguistik Dan Sastra, 12-21.

Wisudayantia, K. H. (2018). An Analysis of Interlanguage Error on Writing Functional Text Application Letter by Meditteranean Students. THE FOURTH INTERNATIONAL CONFERENCE ON ENGLISH ACROSS CULTURES (hal. 332). Singaraja, Bali: Undiksha Press.

Richards, J.C. (1971). A Non-Contrastive Approach to error Analysis, English Language Teaching, Vol.25, 3 April 1971. London:Oxford University Press.

Richards et.al. (1992). Dictionary of Language Teaching \& Applied Linguistics. New Edition. UK: Longman Group

Selinker, Larry. (1997). Rediscovering Interlanguage. London: Longman

Urquhart,Vicki and Monette Mclver.(2005).Teaching Writing in the Content Areas. New York:McREL Allright received. 